$\mathrm{n}=$ nucleus.

nc $=$ nerve-cord.

ns $=$ neural septum.

$œ=$ œesophagus.

$œ v=$ esophageal valve.

pe $=$ peritoneal membrane.

ph $=$ pharynx.

pm= peritrophic membrane.

$\mathrm{pp}=$ pharyngeal pump.

pro $=$ prothorax.

$\mathbf{R}$, rec $=$ rectum. $\mathrm{s}=$ setæ.

$\mathrm{sg}=$ salivary glands.

sgd = salivary gland duct.

sœ= subœsophageal ganglion .

$\mathrm{tg}=$ thoracic ganglion.

$\mathrm{tm}=$ transverse muscles.

$\operatorname{tr}=$ trachea .

$\mathrm{vm}=$ valve muscles.

$\mathrm{y}=$ yolk.

$1,2,3=$ coxæ.

\title{
ON THE EARLY STAGES OF SOME WESTERN CATOCALA SPECIES.
}

\section{By Wm. Barnes M. D. and J. MeDunnough Ph. D.}

Decatur, Ill.

It was our good fortune in the autumn of 1912 to obtain ova of several species of Catocala whose early stages had never been studied. Most of these we successfully bred through to the adult stage; colored figures of the larvæ have been made and will be published later in connection with Beutenmüller's Monograph of the Genus Catocala, which we have been asked by the trustees of the American Museum to revise and complete for publication; in the meantime we offer the following notes on the larval stages. The species in question may be roughly divided into two groupsthe oak feeders, comprising zoe, aholibah, ophelia, beutenmuelleri, and desdemona, and the willow and poplar feeders consisting of faustina, californica, irene, pura, and the species going under the name of aspasia Strecker. These two groups may be readily separated in the first larval stage by the fact that the setæ arising from the primary tubercles are much longer in the oak feeders than in the willow and poplar feeders, giving the former under a lense quite a spiny appearance, whereas the latter appear almost smooth. Among themselves the larvæ of each group are very similar in the first stage; the oak feeders are of a bluish-gray color with more or less strongly developed deep brown lateral blotches on the first four abdominal segments, 5-6 brown lateral lines and at times a similar centro-dorsal line; the presence of this dorsal 
line in Stage 1 separates zoe and aholibah from the other three species; these two may be distinguished from each other, apart from the ova, which are very dissimilar, by the fact that the brown lateral blotches in aholibah tend to form more or less evident transverse banding and the two spiracular lateral lines are more broken than in zoe; in later stages the two species diverge widely from each other. Of the other three desdemona is distinguished by possessing 6 lateral brown lines in Stage 1 instead of 5 as in beutenmuelleri and ophelia; of these latter two species ophelia shows two subdorsal lines in Stage I which are not developed in beutenmuelleri until Stage II. In the later stages of all these species the spaces between these brown lines gradually become paler than the ground color, forming stripes to which the lines act as a border, becoming more wavy in character and finally breaking up into a series of dots scarcely to be distinguished from the general surface of the body which is strongly sprinkled with similar dots; the dorsal stripe with its characteristic diamond-shaped enlargements on the abdominal segments appears usually in Stage II, either as pale irregular bordering to the centro-dorsal line, or failing this line as a pale stripe between the two subdorsal lines, in which case the centro-dorsal line makes its appearance later.

The willow and poplar feeders bear still more resemblance to each other than the oak group and are almost indistinguishable from one another in Stage I. All have a reddish-brown head and a pale greenish body shading into purplish or blackish laterally, this darker portion crossed by three pale rather waved lines; aspasia is the palest, and is almost entirely whitish-green with only faint traces of the lines; calijornica is the darkest, being laterally almost black in Stage II; the others are intermediate. The development of the maculation is the direct antithesis of that found in the oak-feeders; the stripes develop directly from the pale lines of Stage I, the darker bordering lines (the only ones visible in the 1st stage of the oak-feeders) appearing only in the 2nd or 3rd stages.

We append a more detailed description of the various stages:Catocala zoe Behr.

Ovum. Large, echinus-shaped, liver-brown with irregular ring of yellow around widest part; strongly ribbed, about 16 ribs diverging from the micropylar area and branching into 2 or 3 almost immediately, these ribs crossed at right angles by 
very fine ribbing; micropylar area a rosette of minute cells. Width, $1.5 \mathrm{~mm}$. Height, .8 mm.

Stage I. Head flat, black; body blue-gray; a dark dorsal line; a lateral band paler than the ground color, bordered on each side by a fine dark line and containing a similar central line; two further dark subspiracular lines; on abdominal segments I-IV small round deep brown patches laterally; primary tubercles black, prominent especially those situated ventrad to the pale lateral stripe, each with a long black seta Beneath pale gray with central dark blotches. Length, $6 \mathrm{~mm}$. Width of head, .5 mm.

Stage II. Head whitish, strongly marbled with black, with two black lines in front, bending away from each other as they approach apex of cheeks, a central dark line in clypeus and a curved line around lateral portion of the cheeks; body gray with dark brown dorsal line irregularly bordered with whitish, this color tending to spread out into diamond-shaped patches towards rear of each segment and defined outwardly by a blackish line; lateral whitish band as before with dark borders and central line; below this a black line on a level with tubercle IV; a 5th subspiracular line bordered dorsally with whitish; dark blotches on abdominal segments 1-4 as in previous stage; tubercles large, black, increasing in size towards posterior end; prolegs with a strong black chitinous lateral plate. Beneath whitish with dark central blotches. Length, $12 \mathrm{~mm}$.

Stage III. Head as in previous stage; on the body the light stripes of the previous stage have so broadened that the general ground color appears light gray slightly mottled with flesh color, the darker portion being confined to a subdorsal irregular band and a similar lateral band in the region of tubercle III; a light gray, very irregular dorsal band defined outwardly by black lines and broadening into diamond patches at the rear of each segment with a dark centro-dorsal line; the subdorsal dark areas are more or less shaded with gray anterior to tubercle II; lateral gray area and dark lines as before; ventrad to this is the lateral dark area on a level with tubercle IV, paler on thoracic segments, with mere traces of dark lateral patches of previous stages, bounded ventrally by dark line; the light area ventrad to this contains two dark lines, the lower forming the outer margin; dorsal tubercles conical, shaded black and white, especially large on 8th abdominal segment; a small transverse dark wart dorsally on 5 th abdominal segment. Beneath whitish with black central patches. Length, $18 \mathrm{~mm}$.

Stage $I V$. Head gray strongly striate with black; a black upright dash in central front portion of cheek and a broad curved lateral line of same color; body pale gray, marbled, rough and tubercular in appearance; markings essentially as in preceding stage; the pale gray dorsal stripe with diamond-shaped enlargements is usually quite prominent owing to its being bordered by a darker gray subdorsal stripe, deepest in color on the 1st, 2nd and 5th abdominal segments; dark supraspiracular stripe distinct, paler in anterior portion and on 4th abdominal segment; dorsal tubercles pale, ochreous, raised, with more or less of a transverse ridge between the two tubercles II, especially marked on 1st, 2nd, 5th and 8th abdominal segments; on 5th abdominal segment a small dark transverse dorsal wart, shaded posteriorly with blackish; tubercle II on 8th abdominal segment large and conical; tubercle IV situated on a rather raised wart just behind spiracle; below 
this a dark line in a paler field is distinguishable. Beneath pinkish white with the usual dark blotches. Length, $30 \mathrm{~mm}$.

Stage $V$. Head pale ochreous, the upper portion of the lobes tinged with orange, marbled with dark purple-gray with black lateral line descending as far as the ocelli; slight central black line to clypeus. Body very warty both dorsally and laterally, with deep lateral indentations above and below the spiracular area, pale gray, marbled with olive brown, maculation quite similar to that of the preceding stage; dorsal stripe pale gray, irregular, broadening at rear of each segment into diamond-patches which are tinged with ochreous on abdominal segments 1-4; subdorsal stripe dark brownish, broad, waved, prominent behind tubercle II on abdominal segments 1-3, 5 and 8, paler and more diffuse on the other segments; dark spiracular stripe, paler on the thoracic segments, abdominal segment 4 , the anterior portion of 5 and posterior portion of 6 ; abdominal segments more or less humped dorsally between tubercules II, most so on 5 and 8; tubercles situated on a raised hump, tinged with ochreous. Lateral filaments whitish. Beneath deep purple-pink with blackish central patches. Length mature, $40 \mathrm{~mm}$.

Food-plant: Buds and catkins of burr-oak.

The young larvæ emerge with the first warmth of spring, all the ova hatching within a short period of each other; the growth is very rapid, maturity being reached in less than a month; the pupal stage is about three weeks.

The species is very easy to raise, the critical period being just before attaining full growth, when the larvæ seem liable to intestinal troubles which are apparently more or less contagious. In our brood there was also a noticeable difficulty in properly shedding the larval skin in transforming into the pupa.

\section{Catocala aholibah Stkr.}

Ovum. Dark dirty green, surface of egg strongly granulate but without ribs; micropylar area scarcely visible as a rosette of minute hexagonal cells. Diameter, $2 \mathrm{~mm}$.

Stage I. Head deep brown, prothoracic plate black; body bluish-gray with brown dorsal line, three brown lateral lines of which the middle one is most distinct; two similar subspiracular lines the upper one rather curved and much broken; abdominal segments 1-4 crossed by broken broad transverse brownish bands, heaviest laterally; tubercles large, black, with long setæ. Beneath pale with central dark blotches. Length, $6 \mathrm{~mm}$.

Stage II. Head pale brown, strongly veined with black-brown, forming a line on each side arising from the mouth and curving outwards and upwards, broadest towards apex of lobes; central dark line to clypeus; body pale brown, slightly banded with brown on abdominal segments as before; a brown dorsal line broadening slightly towards rear of each segment and irregularly bordered with creamy, forming more or less distinct diamond-shaped patches as usual; two pale slightly 
waved lateral lines and a third subspiracular one, much curved; tubercles large, black; slight dorsal transverse wart on the 5 th abdominal segment and more prominent conical protuberance on dorsal portion of 8 th; prolegs pale with black stripes. Beneath whitish with prominent black patches. Length, $10 \mathrm{~mm}$.

Stage III. Head pale, strongly lined with black, apex of lobes tipped with orange behind which is a heavy black curved line; body gray-purple with distinct black tubercles which at times are orange-tipped; a prominent transverse blackish wart on 5 th abdominal segment and a conical protuberance tipped by tubercle II on 8th; similar lesser prominence on the 9th; lines and stripes as in preceding stage but broader and less distinct; lateral black shading below transverse wart of 5 th abdominal segment. Length. $18 \mathrm{~mm}$.

Stage IV. Head pale creamy strongly lined with black in front and with apex of lobes tipped with orange behind which is heavy black marking. Body purplebrown, the 1st abdominal segment with pale creamy suffusion between and lateral to tubercles I and II, often very faint; stripes of previous stage not distinguishable but the black border lines have broken up into a series of irregular dotted lines on a more or less whitish ground, giving a general mottled appearance; tubercles orange, tipped with black and ringed at base with white, the black color often predominating; transverse wart of 5th abdominal segment black, tipped with white at apex and defined laterally by the orange tubercles II; laterally to this is more or less oblique dark suffusion; prominent hump on 8th abdominal segment tipped by large conical tubercles II, orange in front; black posteriorly. Beneath whitish with black central blotches. Length, $30 \mathrm{~mm}$.

Stage $V$. Head pale ochreous, pitted, marbled with purplish gray with tips of lobes tinged with umber-brown, beneath which is a blackish dot and behind which on the dorsal portion of the lobe is a broad black stripe slightly curved at each end but not descending downwards below the level of the umber-brown area. Body pale liver-brown with numerous black dots encircled with white the remnant of the lines of earlier stages; tubercles coral or deep brown ringed at base with white; transverse wart of 5 th abdominal segment whitish strongly marbled with black; 6th and 7th abdominal segments laterally and posteriorly slightly discolored with brownish; 8th abdominal segment with strong dorsal hump on which are situated tubercles II, large, conical, directed backwards, umber tipped with black; spiracles situated in pale area, black-rimmed; legs pink, shields of prolegs, prothoracic and anal plates ochreous; filaments white; first abdominal segment between tubercle II and spiracle slightly paler, the remains of the patch of the previous stage. Beneath white with black and brown central blotches. Length, $60 \mathrm{~mm}$.

\section{Food-plant: Buds and catkins of burr-oak.}

The emergence and habits of the young larvæ coincide with those of zoe; in all its stages the species shows a close resemblance to sponsa of Europe. Ova from Truckee, Calif. and Provo, Utah gave rise to similar larvæ, the resulting imagines being also identical except that the Utah specimens were generally larger. About 1-4 of the Utah larvæ gave the form coloradensis Beut. which is a 
mere aberration in which the primaries are distinctly paler and the brown band beyond the t. p. line more marked in consequence.

\section{Catocala beutenmuelleri B. \& McD.}

Ovum. Flat, strongly ribbed; micropylar area forms a slightly raised button with central depression containing the micropyle jtself; from the rim of this area 17-20 broad unbranched ribs arise, crossed at right angles by numerous fine wavy cross-ribs. Color purple with yellow ring a short distance above the base. Diameter, $1 \mathrm{~mm}$.

Stage I. Head black. Body pale.gray with 3 brown lateral stripes; diffuse brown patches laterally on 1st four abdominal segments with traces of a 4th brown line posterior to them; below these a 5 th subspiracular line; tubercles black, small, with long setæ. Beneath pale with central dark blotches. Length, $4 \mathrm{~mm}$.

Stage II. Head pale gray, heavily mottled with brown except in front and with two heavy dark curved lines below apex of lobes not reaching lower than apex of clypeus; five equidistant lateral and subspiracular lines as before, the 3rd line rather waved, the lower line distinct; dark lateral abdominal patches much fainter than in preceding stage; dorsal region with two brown lines narrowing between tubercles I and spreading out towards rear of segments tending to form diamond-shaped patches of the enclosed space; traces of a centro-dorsal line between tubercles I on abdominal segments; on 5th abdominal segment a slight raised dorsal wart; on 8th abdominal a sma!I conical projection; tubercles black with setæ as before. Length, $9 \mathrm{~mm}$.

Stage III. Head as before but more striate with black. Body and markings essentially as before but pale dorsal diamond-shaped patches more noticeable and the dark lines appearing more as border lines to enclosed yellowish stripes; small transverse wart on 5th abdominal segment; the rear portion of this segment and anterior portion of 6 th shaded with blackish; 8th segment raised dorsally with conical reddish tubercles and a small black lunate mark posterior to these; prolegs with black stripe. Length, $15 \mathrm{~mm}$.

Stage IV. Head pale strongly marbled, apex of lobes slightly orange, below which is a small blackish curved mark; behind the apex of lobes a curved double black line extending laterally down the sides of the cheeks. Body gray, somewhat ochreous at the incisions of the first four abdominal segments; lines and stripes much as before but fainter, the former being broken up into a series of dots; tubercle on 5th abdominal segment black, prominent, with dirty brown oblique patch extending laterally downwards to base of prolegs; tubercles deep orange, those on 8th abdominal segment situated on a strong hump behind which is a curved orange mark; prolegs pale, striped with black; beneath whitish with the usual black patches. Length, $25 \mathrm{~mm}$.

Stage $V$. Head purplish gray marbled in the front of the lobes with darker; the two tubercles at the apex of the lobes tipped with orange with dark blackish curved mark behind the apex. Body light gray, fairly smooth, with small oblique ridges on the anterior abdominal segments extending laterally forward from tubercle II; pale dorsal stripe with diamond-shaped enlargements; remainder of body heavily marbled with black dots, representing the dark border lines of previous 
stages; a very prominent fleshy beak-like wart on 5th abdominal segment shaded with black and with black posterior markings extending obliquely downward over the anterior portion of the following segment; laterally the 5 th segment is shaded with light brown extending between the prolegs on to the 6th segment; prominent conical dorsal tubercles on the 8th abdominal segment with lunate brown mark behind extending to above spiracle; filaments whitish; beneath white with central black blotches. Length, $40 \mathrm{~mm}$.

Food-plant: Buds and catkins of oak.

The larvæ emerged about a week later than zoe and aholibah maturing rather more slowly than these two species; a number of the full grown larvæ refused to pupate but gradually shrivelled up and died; it is probable that better results would be obtained by isolating the larvæ in the last stage. The prominent dorsal wart on the fifth abdominal segment would place the species in the ultronia group. In our opinion beutenmuelleri will prove to be a local race of verrilliana but we can find no larval description of this species. We cannot agree with Hampson who makes this species and werneri Bied. synonymous; this latter species, of which the type is in Coll. Barnes, shows much more affinity to violenta Edw. and we should not be surprised if it proved to be a mere aberrant form of the same; ophelia $\mathrm{Hy}$. Edw. we have proved by breeding to be a species very distinct from beutenmuelleri and presumably therefore from verrilliana; breeding alone will show how closely it is related to violenta Edw.

\section{Catocala ophelia Edw.}

Ovum. Hemispherical, much higher than beutenmuelleri; ribbed, about 20 ribs attaining the edge of the raised circular micropylar area, every second rib branching dicotomously in contradistinction to the preceding species where the ribs always remain single; color liver-brown with yellow ring near the base. Diameter, $1.2 \mathrm{~mm}$.

Stage I. Head blackish; body blue-gray more or less completely banded with brown on the first four abdominal segments, tending to form lateral and dorsal blotches; tubercles black with long black setæ; geminate rather waved dorsal brown lines situated in the area between tubercles I and II and tending to separate towards rear of each segment; three lateral brown lines and two further subspiracular ones. Beneath whitish with brown central patches. Length, $6 \mathrm{~mm}$.

Stage II. Head pale gray, marbled with black with inverted V shaped black mark on front of each lobe and central black dash on clypeus. Body pale yellowish gray with black tubercles and traces of lateral purplish patches of previous stage; markings as before with the addition of a centro-dorsal broken stripe, thickened slightly at intervals. Length, $11 \mathrm{~mm}$.

Stage III. Head same as before. The lines on the body of the previous stage 
now appear as border lines to three pale ochreous stripes; dorsal stripe broadening to the usual diamond shaped patches and with central dark line, thickening in these same patches; small dark transverse tubercle on 5th abdominal segment; dorsal protuberance on the 8th abdominal segment with large conical flesh-colored tubercles; 9th segment similar but smaller. Length, $18 \mathrm{~mm}$.

Stage IV. Head pale with V mark and central dash as before; apex of lobes tinged with orange; cheeks bordered by a double black curved line. Body pale gray, the markings essentially as before but fainter, the black border-lines broken up into dots, the lateral stripes most marked between prolegs of 5th and 6th abdominal segments, the ground color being here somewhat darker; dorsal wart on 5th abdominal segment small, shaded with blackish; tubercles orange, II on the 8th abdominal segment large, extended backward and situated on a prominence. Beneath white with black central patches. Length, $30 \mathrm{~mm}$.

Stage $V$. Head pale purple-gray, apex of lobes white, slightly lined with orangered and purple, the white color extending down cheeks frontally in irregular lines; a black lateral border line to cheeks shaded inwardly with orange. Body deep gray, smooth, heavily dotted with black; stripes of the previous stages fairly distinct; tubercles small, brick-red, tubercle II on 8th abdominal segment large, situated on prominence; wart on 5th abdominal segment small dusky; an ochreous subspiracular stripe between prolegs of 5 th and 6 th abdominal segments, shaded dorsally with deep smoky gray; filaments whitish. Beneath white with the usual dark central patches. Length, $40 \mathrm{~mm}$.

\section{Food-plant: Buds and catkins of burr-oak.}

The species may at once be separated from the preceding by the lack of the prominent hump on the 5th abdominal segment and the presence of an ochreous patch between prolegs of 5 th and 6th abdominal segments. It coincides with beutenmuelleri in its general habits. The parent moth was captured at Provo, Utah.

\section{Catocala desdemona Edw.}

Ovum. Pale yellowish, very finely ribbed with numerous branching ribs, hemispherical; micropylar area slightly raised, circular.

Stage I. Head brownish; body pale gray with fairly large black tubercles and brown lateral patches on abdominal segments 1-4 tending to broaden into transverse bands; three brown lateral lines and traces of three further lines below these the upper two of which are only visible behind the lateral brown patches. Beneath pale with central brown blotches. Length, $6 \mathrm{~mm}$.

Stage II. Head gray with curved black line in frontal portion of cheek curving outward toward apex of lobes; central black line on clypeus. Body gray with pale germinate dorsal stripes bordered with dark brown and tending to coalesce; two pale lateral stripes similarly bordered; a third subspiracular one; a faint brown line defines the pale ventral area; traces of the dark lateral patches still present. Length, $13 \mathrm{~mm}$.

Stage III. Head pale gray slightly tipped with orange; dark W mark in frontal 
portion of cheeks and dark curved lateral border to same; clypeus with central dark line. Body pale gray; dorsal and three lateral creamy stripes prominent, bordered by brown lines; 5th abdominal segment with small dorsal wart tipped with reddish at apex; from this wart a dusky lateral shade extends downward to the prolegs, crossed by the pale lateral stripes; tubercles reddish, tubercle II of 8th abdominal segment conical, with dark lunate reddish line posterior to it; prolegs striped with black. Luength, $18 \mathrm{~mm}$.

Stage $I V$. Head gray, apex of lobes tinged with orange-red; lobes strongly marbled vertically forming W mark frontally; geminate lateral black curved line and central line to clypeus. Body gray with paler creamy stripes; dorsal stripe, as usual, tending to diamond-shaped enlargements, with centro-dorsal dark line and similar colored border-line, most prominent at rear of 1st four abdominal segments; three pale lateral stripes bordered with blackish lines which tend to break up into dots; on 1st abdominal segment a dark oblique lateral shade extends forward from tubercle II toward the 3rd pair of legs; dorsal wart on 5th abdominal segment flesh-colored with diffuse darkish shade extending from it laterally to prolegs; tubercles „orange; curved line behind the conical dorsal tubercles on 8 th abdominal segment brownish. Beneath whitish with the usual dark blotches. Length, 20-30 mm.

Stage $V$. Head whitish tinged with orange in front and along sides of cheeks; pale purple gray marbling in front forming a W mark, black border stripe to cheeks laterally. Body pale to dark gray caused by numerous dark dots on a whitish ground; dorsal and lateral stripes of previous stage distinct, latter waved and irregular, the dark border lines broken up into dots, most distinct behind tubercle II on first 5 abdominal segments as lower border of the dorsal stripe and upper border of the first lateral one; on first abdominal segment an oblique pale shade running from tubercle II to beyond spiracle and bordered posteriorly slightly with dark gray; wart on 5th abdominal segment fairly large, tipped with white, with brown marbling at base, lateral to this wart an oblique brownish shade crossed by the pale stripes and with the ground color showing on a level with the spiracle as a dark gray crossstripe; reddish lunate dorsal line on 8th abdominal segment posterior to the large conical tubercles II; tubercles orange with white base; prolegs pinkish marbled with brown; filaments white. Beneath white shaded with pink with the usual dark central blotches. Length, $50 \mathrm{~mm}$.

Food-plant: Buds and catkins of burr-oak.

This species was the latest of the oak-feeders to emerge; after reaching its full size the larvæ seem to find difficulty in pupating, a number of ours dying at this stage. The larva is considerably larger and more variegated than that of either ophelia or beutenmuelleri.

\section{Catocala pura Hlst.}

Ovum. Hemispherical, deep purplish-red banded with yellowish near base, ribbed, the ribs branching into two or three shortly after leaving micropylar area 
which is slightly raised. Very similar to the egg of C. faustina. Diameter, 1.25 mm.

Stage I. Head red-brown. Body when first emerged blackish, later dirty green shaded with purplish anteriorly and posteriorly, with three pale lateral lines; tubercles small, black, with short setæ. Beneath paler with faint central dark blotches. Length, 5-6 mm.

Stage II. Head pale creamy, cheeks slightly marbled with light brown; body light brown, the three pale lines have broadened into waved stripes bordered with darker lines; a pale dorsal stripe, expanding more or less into diamond patches and with trace of centro-dorsal line; 5th abdominal segment with slight transverse black wart from sides of which an oblique black patch extends backward and downward to just above the prolegs of 6 th segment; a lunate dorsal black line on 8th abdominal segment the dorsal tubercles of which are slightly raised and conical; all other tubercles very minute; prolegs pale. Length, $15 \mathrm{~mm}$.

Stage III. Head creamy tinged with orange below the apices of the lobes, pale brown frontal marbling, two lateral deep brown lines on the cheeks. Body pale gray-green, having a general marbled appearance; marking essentially as in previous stage, the pale stripes however are scarcely distinguishable and the brown border lines appear prominent, giving the appearance of 7 waved lateral lines and a similar dorsal one; rear portion of 5 th abdominal segment velvety-black, this color extending obliquely downwards to prolegs of 5 th and 6 th segments; a small dorsal wart tinged with orange situated in this black area; tubercles pale orange, tubercle II on 7th abdominal segment tinged posteriorly with black, on 8th with a black lunate dorsal mark, slightly broken in the center posterior to this tubercle. Length, $25 \mathrm{~mm}$.

Stage IV. Head creamy, apical portion of lobes orange below which is pale brown marbling, cheeks with dark curved border-line. Body pale gray-white, the blackish border-lines resolved into dots giving a general marbled appearance; transverse orange wart on 5th abdominal segment with the black shading of the previous stage less pronounced, only traces of this color being visible above the prolegs; tubercles orange, tubercles II on 8th and 9th abdominal segments being situated on conical prominences, the former the larger; lunate black mark on 8th as before but unbroken; dorsal diamond patches on abdominal segments shaded with pale orange-brown. Length, $30 \mathrm{~mm}$.

Stage V. Head pale gray; apical portion of lobes with rather prominent tubercle shaded broadly with orange; purplish marbling and black lateral border as before. Body round and smooth, pale whitish gray, heavily sprinkled with black dots which tend to form wavy longitudinal lines; pale dorsal diamond patches faintly visible, slightly tinged with ochreous; prominent reddish ochreous hump on 5th abdominal segment at times with traces of the black lateral shading of former stages, often entirely without this; lunate mark of 8th abdominal segment less distinct than before, tubercle II prominent, conical; legs flesh-colored; filaments grayish. Beneath white with the usual dark central patches. Length, $60 \mathrm{~mm}$.

Food-plant: Poplar.

The ova start hatching soon after the first warm weather in spring the period of emergence extending over several weeks. 
We were very successful with this species and secured a long series of moths; two forms were represented in about equal numbers-the typical one with black shade extending nearly the whole length of wing above inner margin and a form in which this shade was lacking, the wing being more even gray; both these forms were the offspring of a single $q$.

\section{Catocala aspasia Stkr.}

Ovum. Liver-brown, micropyle and broad irregular ring at upper part of egg pale greenish yellow; ribbed but not very strongly, the ribs dividing below micropylar area into about $30-40$. Diameter, $1 \mathrm{~mm}$.

Stage I. Head pale brown; body pale greenish white, semitransparent, shading slightly into reddish laterally with traces of three pale lateral lines; tubercles very minute with small setæ. Length, $5 \mathrm{~mm}$.

Stage II. Head creamy, slightly marbled with pale brown; body whitish, slightly green tinted, an irregularly broadening dorsal stripe and three lateral ones are visible largely due to the pale brown linear borders; a faint trace of brownish lateral shading on 5th abdominal segment, prolegs concolorous. Beneath pale with dark central patches. Length, $12 \mathrm{~mm}$.

Stage III. Much as before; head shaded slightly with pale yellow at apex of lobes; body with stripes less visible and bordering lines broken up into dots, giving a general marbled appearance; very small wart on 5th abdominal segment, slightly yellow, with still fainter traces of lateral black shading; tubercle II on rear segments slightly yellow with traces of a lunate dorsal black mark on the 8th abdominal segment as found in pura. Length, $20 \mathrm{~mm}$.

Stage IV. Head whitish, clypeus slightly marked with pale brown, apex of lobe tinged with yellow-orange below which is brownish marbling of which a dash on a level with side of clypeus is most prominent; black border line to cheeks extending to eyes and not very clearly defined on the summit of the head. Body whitish gray with much clearer markings than before; dorsal series of pale diamond patches with central brown line; subdorsally two waved black dotted lines the upper one forming border to diamond-patches, the lower one on a level with tubercle III, most prominent toward the rear of each segment giving a distinctly blackish appearance; laterally the body surface is thickly covered with black and brown dots formed into more or less parallel lines, the enclosed spaces being slightly tinged with lemon yellow; prominent yellowish hump on 5th abdominal segment at times slightly shaded with black laterally but mostly without this; small blackish dorsal lunate mark on 8th abdominal segment; dorsal tubercles yellowish, tubercle II on rear segments not very prominent; prolegs tinged with pinkish. Beneath white. Length, $35 \mathrm{~mm}$.

Stage $V$. Head creamy, clypeus with two vertical purple-black dashes; apex of lobe strongly tuberculate, orange; black border laterally to cheeks extending from palpi upwards, not clearly defined on summit of head; purplish marbling in front forming small patch below the orange tubercle and a vertical dash opposite clypeus. Body varying from pale ochreous to pale brown, sprinkled with deeper 
colored dots, usually with subdorsal blackish band formed of numerous spots defining the pale diamond shaped patches, most accentuated behind tubercle II; a similar but less distinct spiracular band; tubercles yellow-ochre, small; wart on 5 th abdominal segment not prominent, tinged with ochreous; vague traces of a black donsal lunate mark on 8th abdominal segment; tubercle II on this segment not much larger than on preceding segment; legs and prolegs pale tinged with pinkish; spiracles ochreous ringed with black, filaments pale. Beneath whitish with the ordinary black blotches. Length, $45 \mathrm{~mm}$.

Food-plant: Poplar.

The larva emerges somewhat later than pura; we brought a number of larvæ to maturity but they all failed to pupate and gradually shrivelled and died. Strecker's aspasia was described from Lower California and we are in doubt whether the name will apply to the form found in Utah and Colorado which commonly goes under the name aspasia. The larvæ in Stage III show great similarity with the final stage of pura, but in their maturity apparently approach closest to parta.

\section{Catocala faustina Stkr.}

Ovum. Echinus-shaped; deep purple-brown with blotches of pale greenish apically and a narrow central band of similar color; micropylar area arising from slight depression at apex of egg, irregularly circular, formed of minute cells surrounded by ring of single larger cells; remainder of surface with longitudinal ribs of which 17-20 attain edge of micropylar area, branching immediately below it either once or twice and forming 35-40 ribs near base of egg; these are crossed by minute transverse ribbing. Diameter, $1 \mathrm{~mm}$.

Stage I. Head pale brown, mouth parts whitish. Body smooth, pale graygreen shading into purplish laterally with 3 pale waved lateral lines; prothorax, anal plates and plates on sides of prolegs gray-brown; tubercles minute black with small setæ. Beneath pale with the usual dark central blotches. Iength, $5 \mathrm{~mm}$.

Stage II. Head red-brown, paler towards front, mottled. Body smooth pale greenish brown, paler than in preceding stage, shading laterally into purplish, this color especially marked above prolegs forming more or less evident blotches; three pale lateral lines as before. Tubercles small, black, larger posteriorly. In later stage of growth a pale irregular dorsal band with diamond patches is visible and there are traces of a transverse reddish wart on 5th abdominal segment. Length $10 \mathrm{~mm}$.

Stage III. Head pale in front, cheeks mottled with brownish with blackish curved lateral line. Body light-brown, pale dorsal irregular band bordered by dark lines and with the usual diamond-shaped enlargements; the three pale lines of earlier stages have broadened into irregular pale reddish bands, defined and bordered by dark lines; a transverse black wart across the rear of 5th abdominal 
segment with slight central reddish portion; lateral black shading on 5th and 6th abdominal segments extending down over prolegs; a black lunate mark on rear of 8th segment dorsally; tubercles red-brown. Beneath whitish with black patches. Length, $20 \mathrm{~mm}$.

Stage IV. Head pale, apex of lobes orange, this color extending downward to the region of the ocelli, the whole frontal area bordered by an encircling black band. Body smooth, slender, pale purple-brown with orange tubercles of which II is the largest, especially on the rear segments; dorsal stripe of previous stage shows strong central brown marbling; the lateral stripes are more or less lost in the brown marbling which is responsible for the general body-color, traces of the defining darker lines may be found in longitudinal rows of dark dots; a prominent pale orange transverse wart with brown basal shading on 5th abdominal segment; laterad to this orange brown shading extends obliquely backward over rear portion of 5 th and front portion of 6 th segments; prolegs pale ochreous, shaded with brown on the contiguous sides; claspers bordered inwardly with blackish; lunate mark on 8th abdominal segment orange-brown bordered posteriorly with blackish; tubercles prominently orange; spiracles situated in a pale area, black rimmed. Length, $35 \mathrm{~mm}$.

Stage $V$. Very similar to the preceding stage. Color pale brown. The lateral oblique patch of brown on 5th and 6th abdominal segments has almost disappeared, when present it is a pale suffused brown, scarcely deeper than the ground-color, crossed by slightly darker shade-lines; filaments whitish. Length, $55 \mathrm{~mm}$.

Food-plant: Willow.

We received a large number of ova laid by typical faustina and the forms diantha, verecunda and zillah. The species seems quite difficult to breed and we had success only with those larvæ which hatched earliest and were fed on willow-catkins; the parent of these was a o diantha and the resulting progeny was about equally divided between diantha and verecunda; larvæ of the other forms attained maturity in numbers but died before pupation; we could see nothing in the larvæ to warrant the supposition that faustina is distinct from verecunda as a species; the eggs hatch over a very extended period and when the first imagines appeared in June we still had young larvæ in the first stage.

\section{Catocala californica Edw.}

Ovum. Not distinguishable from that of C.faustina, deep purple-brown blotched apically with yellowish and with a yellowish central band.

Stage I. Head pale brown; body dark greenish with three pale lateral stripes; scarcely to be distinguished from that of faustina. Length, $5 \mathrm{~mm}$.

Stage II. Head pale, very strongly marked with black. Body greenish-black, deepening in color posteriorly, with pale broad irregularly edged dorsal stripe and three pale waved lateral lines; small black transverse wart on 5th abdominal 
segment almost hidden in the ground-color; tubercles small, black; prolegs pale. Beneath pale with the usual central blotches. Length, $11 \mathrm{~mm}$.

Stage III. Head pale, lobes tipped with orange apically, marbled with brown in front and bordered by a deep brown lateral line. Body pale greenish-brown, paler dorsally; dorsal stripe with central dark line; three lateral pale waved stripes bordered with dark brown; tubercles more or less orange; transverse wart of 5th abdominal segment mostly velvety-black, tipped with orange, with strong lateral and posterior black shading extending down over prolegs of 5 th and 6th segments; tubercles II of 8th abdominal segment conical with black lunate mark posterior to them. Length, $18 \mathrm{~mm}$.

Stage IV. Head with the apical orange shading more extended, front of lobes marbled with pale brown with strong lateral black encircling band. Body pale purplish-gray; a rather vague pale dorsal stripe with diamond-shaped enlargements and central dark line; the three lateral stripes indistinct with the border lines broken up into a series of dots; tubercles orange, tubercle II being more prominent than in faustina; a prominent transverse wart on 5th abdominal segment, orange, blackish at base, with black-brown shading extending obliquely laterally as far as the prolegs, much more distinct than in faustina, 8th abdominal segment with conical tubercles dorsally and lunate black-brown mark as before. Length, $26 \mathrm{~mm}$.

Stage $V$. Head purplish in front, marbled with paler, with diffuse orange shading apically and broad black encircling ine laterally extending downward to mouth parts; clypeus outlined basally with black with blackish central mark. Body purplish-brown heavily mottled with black-brown dots; paler dorsal stripe with diamond patches as before; three lateral pale stripes more or less traceable; tubercles reddish orange, paler laterally; tubercle II prominent, marked posteriorly with black especially on 5th and 7th abdominal segments; prominent wart on 5th abdominal segment, reddish orange, marbled with brown; brown lateral oblique patch as before, crossed by a purple-brown spiracular stripe, above which is some diffuse purplish shading and below which a purplish line extending down over the 3rd and 4th pairs of prolegs; lunate black dorsal mark on 8th abdominal segment usually distinct, extending laterally to spiracles, these latter ochreous, black rimmed; legs and prolegs purplish with ochreous shading, filaments whitish. Beneath whitish tinged with pink with the usual central blotches. Length, 60 $\mathrm{mm}$.

\section{Food-plant: Willow.}

The larvæ are very closely allied to those of faustina but may be distinguished in early stages by the darker coloration and in the final stage by the much greater prominence of the lateral dark patch on 5th abdominal segment. We were not very successful with the brood, only bringing a few to the imaginal state; these all showed the prominent waved white subterminal line and some white patches in the cell. 
Catocala irene Behr.

Ovum. Similar to that of C. californica and faustina.

Stage I. Scarcely to be distinguished from faustina; head pale red-brown; body greenish-gray shading into purplish laterally with three pale lines of ground color. Length, $5 \mathrm{~mm}$.

Stage II. Head whitish, marbled with blackish stripes, with slight tinge of orange apically. Body pale gray-green, laterally greenish-black with three pale waved stripes; a faint dorsal stripe with diamond-shaped enlargements. Length, $11 \mathrm{~mm}$.

Stage III. Head pale with brown marbling, shaded with orange at apex and with black lateral border-lines not meeting dorsally. Body light olive-brown with pale dorsal and lateral stripes as before bordered with deep brown, the lower border of stripe II and the upper one of III especially prominent; transverse wart on 5th abdominal segment reddish with ochreous apex; below the wart a blackbrown lateral shade broken by the pale stripes, deepest in color above stripe III and tending to extend along its dorsal margin towards anal segment; dorsal tubercles orange, larger and conical on 8th abdominal segment with slight black lunate marks behind them not meeting dorsally. Length, $17 \mathrm{~mm}$.

Food-plant: Willow.

We were unsuccessful in bringing the larvæ to maturity. They are evidently also allied closely to faustina.

\title{
THE DISTRIBUTION OF SOME SPECIES OF DROSOPHILA.
}

\author{
By Charles W. Johnson, \\ Boston Society of Natural History, Boston, Mass.
}

In making a careful faunal survey of any given area, covering a number of years, the gradual or sudden appearance of a species common in other sections, is often of greater importance from the standpoint of geographical distribution than the capture of a number of rare species, often widely distributed, but of whose life history or of the factors governing their distribution little is known.

During the early fall, while experimenting with various species of fungi in an effort to breed some Platypezidæ, my attention was called to several dark colored flies which alighted repeatedly on the netting of many of the jars containing decayed fungi. On capturing several of these I was surprised to see Drosophila repleta Woll. (D. punctata Loew), the first I had seen in Boston. I had 

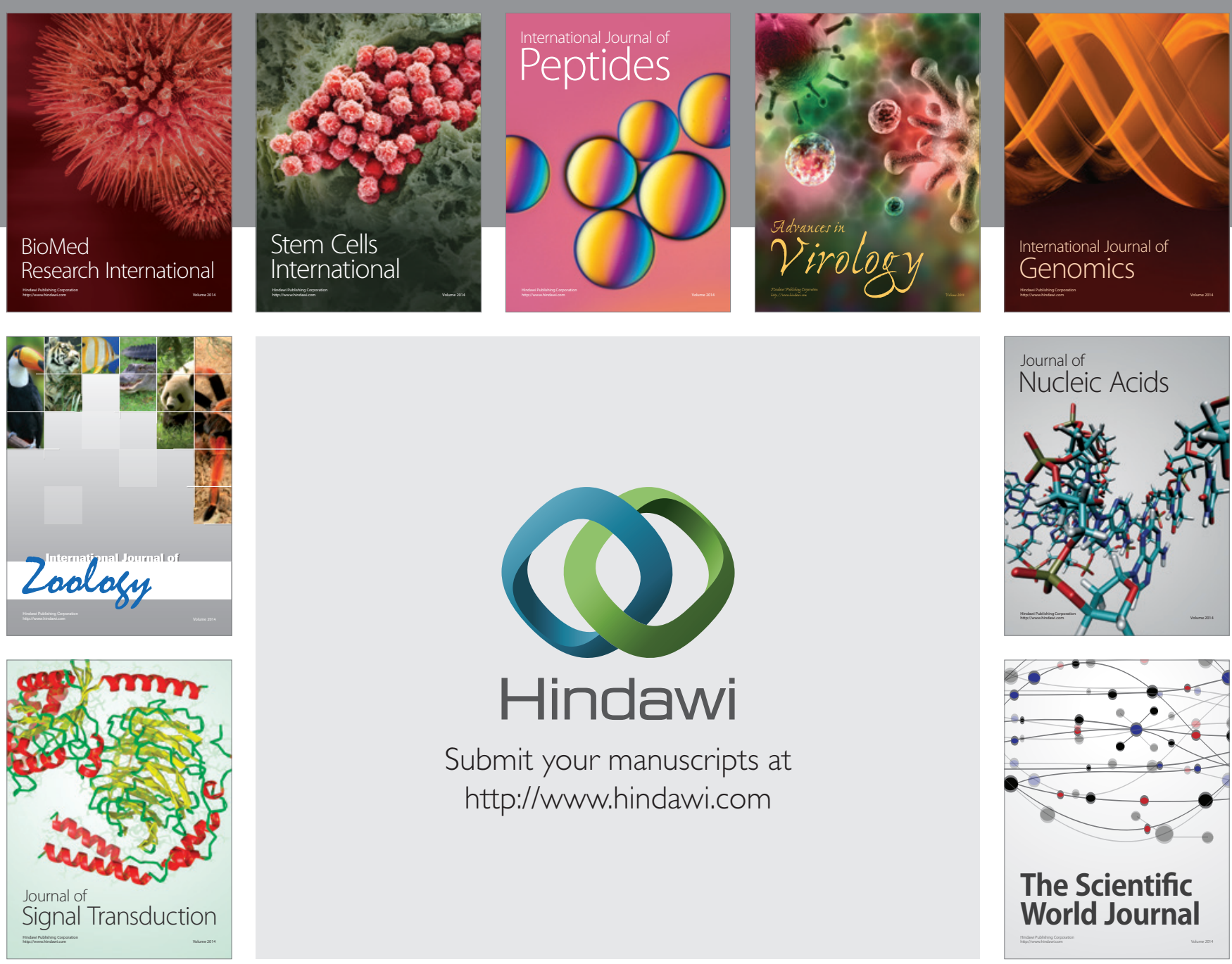

Submit your manuscripts at

http://www.hindawi.com
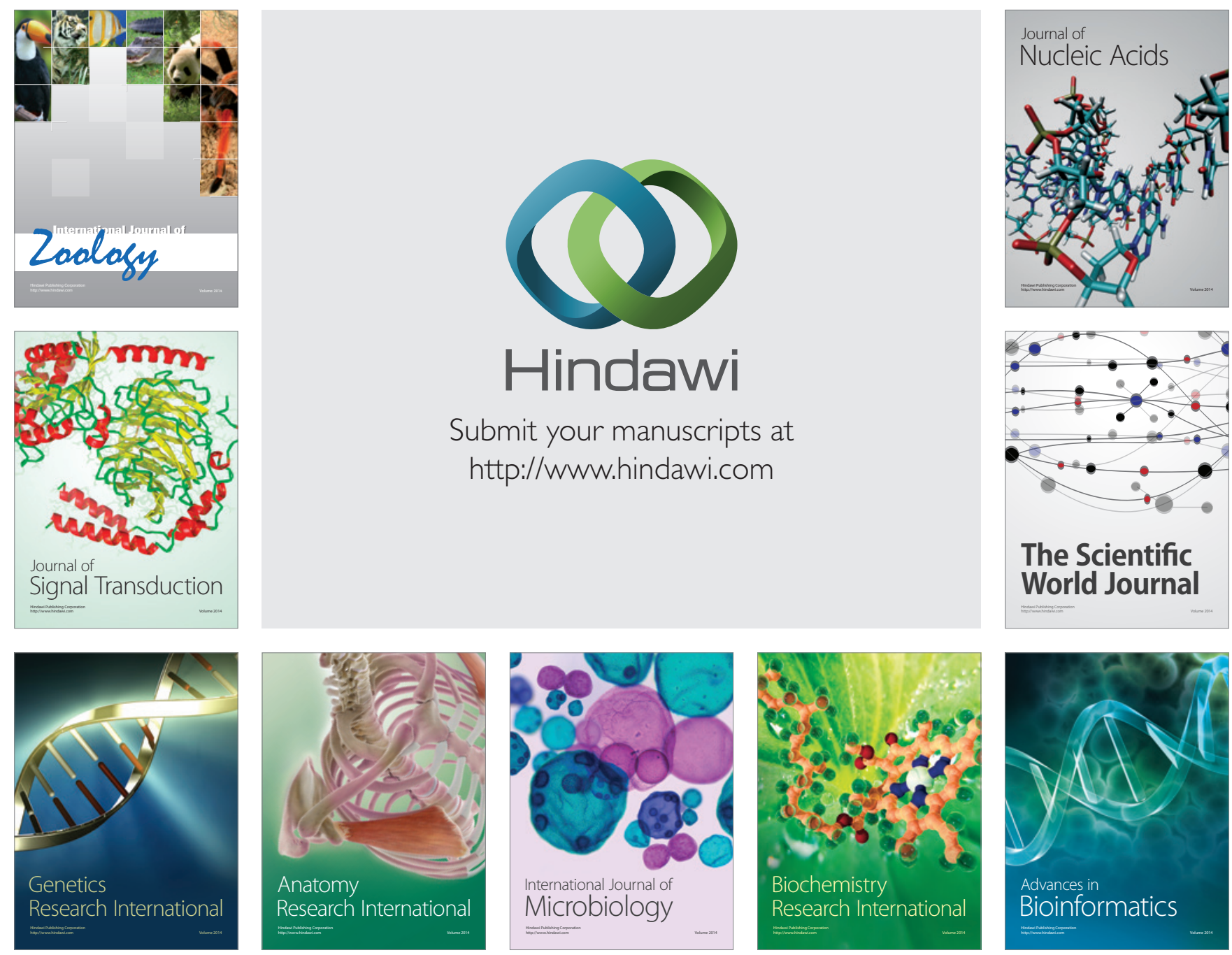

The Scientific World Journal
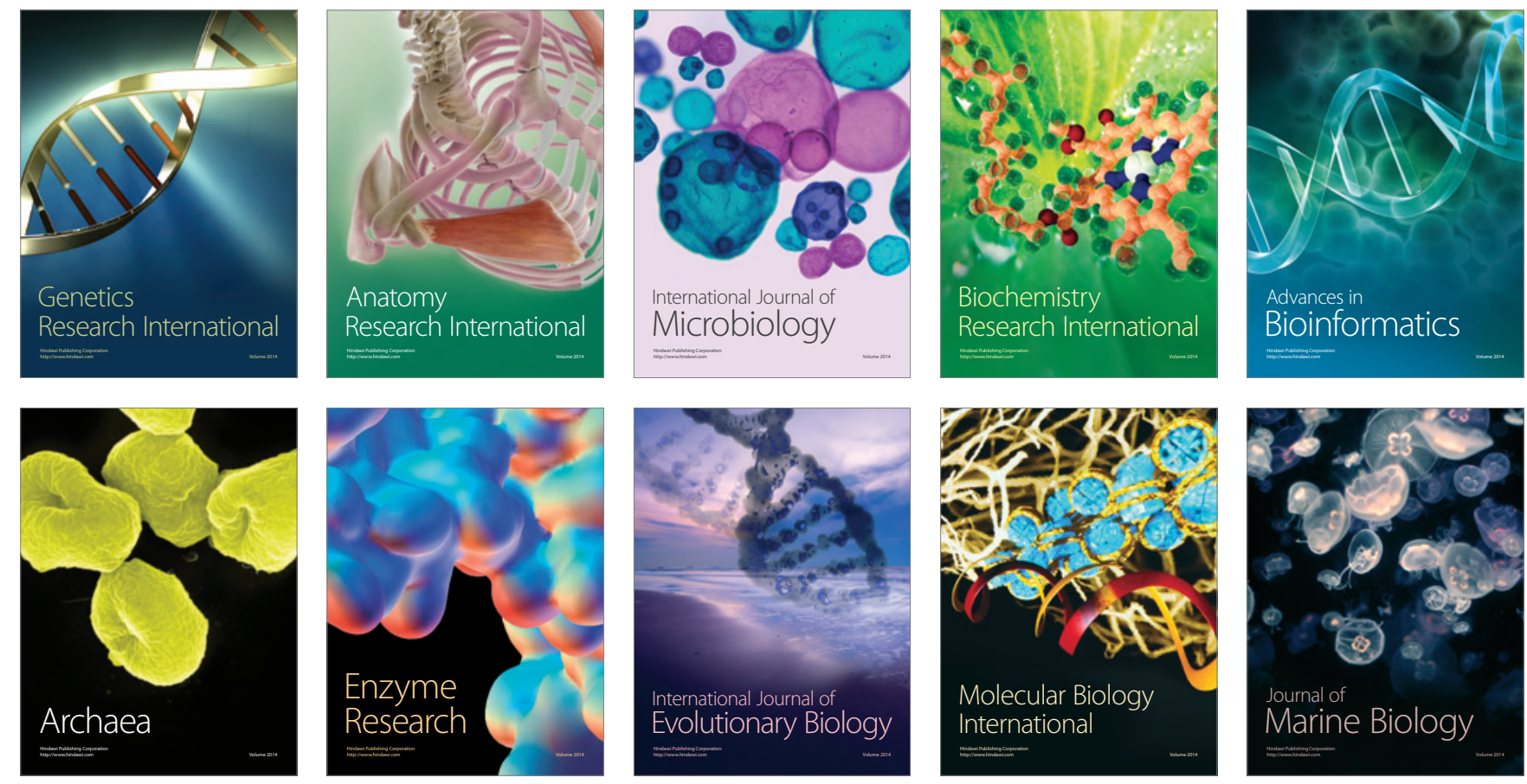